\title{
Efektifitas Herbisida Formulasi pada Gulma Air di Lahan Rawa Tadah Hujan, Rawa Payau dan Saluran Drainase
}

\section{The Effectiveness of Herbicide formulations on Aquatic Weeds in Rainfed Swamp, Brackish Swamps and Drainage Channels}

\author{
Risvan Anwar", Eka Suzanna, Djatmiko, Windi Sambaz Dwi Andika, dan M. Tanu Gurtiwo \\ Program Studi Agroteknologi, Fakultas Pertanian, Universitas Prof. Dr. Hazairin, SH. \\ Jl. Jenderal Sudirman No. 185 Bengkulu 38117, Indonesia
}

Diterima 7 November 2018/Disetujui 16 Mei 2019

\begin{abstract}
A series of studies had been carried out to create new types of herbicides. The studies had found six formulations of herbicides. This study aimed to determine the effectiveness of herbicides formulation in controlling aquatic weeds. The experiment used a randomized complete block design with seven herbicide formulations as treatments and three replications. The seven formulations of herbicide were: Unihaz 1, Unihaz 2, Unihaz 3, Unihaz 4, Unihaz 5, Unihaz 6, and a control (glyphosate $2 \mathrm{~kg} \mathrm{ha}^{-1}$ ). The results of the study found that there were 21 species of weed in rainfed swamps, ten species in brackish swamps and one species namely water hyacinth (Eichhornia crassipes) in drainage channel. Herbicide formulations of Unihaz 3, 4, 5, and 6 were effective in controlling aquatic weeds in rainfed swamps. Herbicide formulations of Unihaz 2, 3, and 5 were effective in controlling aquatic weeds in brackish swamps. All herbicides formulations were effective in controlling weeds in drainage channels. Moreover, herbicide formulation of Unihaz 5 was more effective in controlling aquatic weeds in rainfed swamps, brackish swamps and drainage channels than other formulations, and it was not significantly different from the use of a glyphosate dose of $2 \mathrm{~kg} \mathrm{ha-1}$.
\end{abstract}

Keywords: Eichhornia crassipes, fermented coconut water, organic herbicide, new types of herbicides

\section{ABSTRAK}

Serangkaian penelitian telah dilaksanakan untuk menemukan herbisida jenis baru. Hasil penelitian telah menemukan enam formulasi herbisida. Penelitian ini bertujuan untuk mengetahui efektifitas formulasi herbisida dalam mengendalikan gulma air. Percobaan menggunakan rancangan acak kelompok, terdiri dari tujuh perlakuan formulasi herbisida dan tiga ulangan. Perlakuan tujuh formulasi tersebut adalah Unihaz 1, Unihaz 2, Unihaz 3, Unihaz 4, Unihaz 5, Unihaz 6, dan Kontrol (glifosat $2 \mathrm{~kg} \mathrm{ha}^{-1}$ ). Hasil penelitian menunjukkan bahwa ditemukan 21 jenis gulma di rawa tadah hujan, 10 jenis di rawa payau dan 1 jenis yaitu eceng gondok (Eichhornia crassipes) di saluran drainase. Herbisida formula Unihaz 3, 4, 5, dan 6 efektif dalam mengendalikan gulma di lahan rawa tadah hujan. Herbisida formula Unihaz 2, 3, dan 5 efektif dalam mengendalikan gulma di rawa payau. Herbisida semua formula efektif dalam mengendalikan gulma di saluran drainase. Herbisida formula Unihaz 5 lebih efektif dalam mengendalikan gulma air di rawa tadah hujan, rawa payau dan saluran drainase, dan berbeda tidak nyata dengan penggunaan glifosat dosis $2 \mathrm{~kg} \mathrm{ha}{ }^{-i}$.

Kata kunci: air kelapa fermentasi, Eichhornia crassipes, herbisida jenis baru, herbisida organik

\section{PENDAHULUAN}

Beberapa penelitian menunjukkan bahwa penggunaan herbisida sintetis secara terus menerus dapat berakibat negatif bagi lingkungan seperti pencemaran lingkungan, polusi sumber-sumber air dan kerusakan tanah (Kurniawan

\footnotetext{
* Penulis untuk korespondensi. e-mail: ra.mukomuko@gmail. com
}

et al., 2014). Selain itu herbisida sintetis juga mengakibatkan keracunan pada organisma non target dan tertinggalnya residu herbisida pada produk pertanian. Harga herbisida juga semakin meningkat setiap tahunnya dengan semakin cenderungnya masyarakat menggunakan herbisida. Menurut Supriadi et al. (2012) penggunaan herbisida dalam mendukung produktivitas pertanian mencapai $49.6 \%$.

Serangkaian penelitian telah dilakukan dalam upaya mencari herbisida organik atau setidaknya dapat menghemat penggunaan herbisida sintetik dengan meningkatkan 
efektifitas herbisida. Hasil penelitian Anwar et al. (2013) menunjukkan bahwa air kelapa fementasi mampu menekan perkecambahan gulma Echynochloa cruss-galli. Hasil penelitian Anwar et al. (2014) menunjukkan bahwa air kelapa fermentasi dapat menekan pertumbuhan alangalang. Aplikasi air kelapa fermentasi dosis $400 \mathrm{~mL}$ per polibag dapat membunuh alang-alang sampai 100\%. Hasil penelitian Anwar et al. (2015) menyimpulkan bahwa penggunaan kombinasi herbisida glifosat $2 \mathrm{~mL}$ dicampur dengan $200 \mathrm{~mL}$ air kelapa fermentasi dan $4 \mathrm{~mL}$ glifosat dicampur dengan $100 \mathrm{~mL}$ air kelapa fermentasi efektif dalam mengendalikan gulma alang-alang di polibag. Hasil penelitian Anwar dan Suzanna (2016) menyimpulkan bahwa perlakuan konsentrasi glifosat $2 \mathrm{~mL}$ dicampur dengan $200 \mathrm{~mL}$ air kelapa fermentasi mampu membunuh gulma di perkebunan kelapa sawit belum menghasilkan sebesar 93.8\%, sedangkan pada konsentrasi glifosat $4 \mathrm{~mL}$ dicampur $100 \mathrm{~mL}$ air kelapa fermentasi mampu membunuh 99.2\%. Hal ini menunjukkan penambahan herbisida glifosat pada air kelapa fermentasi sangat efektif dalam membunuh gulma di perkebunan dan dapat menghemat penggunaan glifosat sampai $80 \%$.

Berdasarkan beberapa penelitian tersebut disusun serangkaian formulasi herbisida berbahan baku air kelapa fermentasi dan glifosat atau $N$-(phosphonomethyl)-glycine yang disebut dengan herbisida formula Unihaz. Keunggulan dari herbisida ini adalah sangat sedikit menggunakan bahan aktif glifosat dan efektif mengendalikan gulma. Herbisida berbahan aktif isopropylamine glyphosate yang banyak dijual merekomendasikan pemakaian dengan dosis $6 \mathrm{~L} \mathrm{ha}^{-1}$ (2000 $\mathrm{g} \mathrm{ha}^{-1}$ ). Herbisida ini hanya menggunakan 90-540 g ha $^{-1}$, dengan demikian menghemat pemakaian glifosat $73 \%$ sampai $96 \%$.

Hasil penelitian menunjukkan bahwa pencampuran glifosat dengan air kelapa fermentasi konsentrasi 1\%, 4\% dan $6 \%$ efektif membunuh gulma alang-alang di polibag (Anwar et al., 2015) dan konsentrasi 1\% dan 4\% dengan dosis $50 \mathrm{~L} \mathrm{ha}^{-1}$ efektif membunuh gulma di perkebunan kelapa sawit yang belum menghasilkan (Anwar dan Suzanna, 2016). Pengujian pada gulma yang hidup di rawa tadah hujan, rawa payau dan saluran drainase, untuk mengetahui apakah herbisida ini efektif dalam mengendalikan gulma air perlu dilakukan. Rawa tadah hujan dan rawa payau merupakan lahan yang potensial untuk pengembangan pertanian (Suriadikarta dan Sutriadi, 2007). Lahan rawa ini selalu tergenang sepanjang tahun, namun merupakan wilayah sedimentasi yang subur. Degradasi lahan dan erosi tanah di bagian atas area tangkapan menyebabkan sedimentasi yang umumnya subur dan merupakan lahan potensial berkembangnya gulma (Geremew et al., 2018). Umumnya gulma yang mendominasi adalah jenis rumput dan teki, sebagian kecil gulma berdaun lebar.

Penelitian ini bertujuan untuk mengetahui efektifitas herbisida formulasi terbaik pada gulma air di rawa tadah hujan, rawa payau dan saluran drainase. Penelitian ini dimaksudkan untuk mendapatkan herbisida jenis baru dengan komponen bahan organik yang dominan dan efektif mengendalikan gulma.

\section{BAHAN DAN METODE}

Penelitian dilaksanakan pada bulan Februari sampai dengan Agustus 2018. Percobaan dilaksanakan di lahan rawa tadah hujan, rawa payau dan saluran drainase. Percobaan di rawa tadah hujan dilaksanakan di desa Surau Kecamatan Taba Penanjung Kabupaten Bengkulu Tengah. Percobaan di rawa payau dilaksanakan di lahan Lapangan Golf Rafflesia Bengkulu, Kota Bengkulu. Percobaan di saluran drainase dilaksanakan di desa Kungkai Baru, Kecamatan Air Periukan Kabupaten Seluma Provinsi Bengkulu.

Bahan-bahan yang digunakan adalah Isopropylamin salt $N$-(phosphonomethyl) glycine, ragi tape, air kelapa tua, dan air. Penelitian menggunakan perlakuan monofaktor yaitu formulasi herbisida yang dicobakan pada gulma di lahan rawa tadah hujan, rawa payau dan saluran drainase. Percobaan disusun dalam Rancangan Acak Kelompok. Masing-masing perlakuan diulang tiga kali. Perlakuan formulasi herbisida tersebut yaitu: Unihaz 1; Unihaz 2; Unihaz 3; Unihaz 4; Unihaz 5; Unihaz 6 dan Kontrol (Glifosat $\left.2 \mathrm{~kg} \mathrm{ha}^{-1}\right)$. Dosis herbisida formulasi yang digunakan adalah $50 \mathrm{~L} \mathrm{ha}^{-1}$. Setiap satuan percobaan berukuran $2 \mathrm{~m} \mathrm{x} 4 \mathrm{~m}$. Data yang diperoleh dianalisis dengan Uji F (sidik ragam). Bila uji $\mathrm{F}$ menunjukkan pengaruh nyata atau sangat nyata maka dilanjutkan dengan uji Duncan Multiple Range Test (DMRT) dengan taraf uji 0.05 .

Formulasi herbisida dibuat dengan memfermentasikan air kelapa tua dengan ragi tape. Setiap 10 L air kelapa difermentasikan dengan $20 \mathrm{~g}$ ragi tape. Proses fermentasi dilaksanakan minimal 10 hari. Selanjutnya air kelapa fermentasi tersebut dicampur dengan Isopropylamin $\mathrm{N}$ (phosphonomethyl) glycine dengan konsentrasi 0.18-1.08\%. Perbedaan antar formula pada kandungan Isopropylamin $N$-(phosphonomethyl) glycine. Formula Unihaz $13.6 \mathrm{~g} \mathrm{~L}^{-1}$ (0.36\%), Unihaz $21.8 \mathrm{~g} \mathrm{~L}^{-1}(0.18 \%)$, Unihaz $37.2 \mathrm{~g} \mathrm{~L}^{-1}$ $(0.72 \%)$, Unihaz $45.4 \mathrm{~g} \mathrm{~L}^{-1}(0.54 \%)$ Unihaz $510.8 \mathrm{~g} \mathrm{~L}^{-1}$ (1.08\%) dan Unihaz $69.0 \mathrm{~g} \mathrm{~L}^{-1}(0.9 \%)$.

Sebelum diaplikasi, terlebih dahulu dilakukan analisis vegetasi di masing-masing petakan percobaan untuk mengetahui Nilai Nisbah Jumlah Dominansi (Sum dominance ratio/SDR). Analisis vegetasi menggunakan metode jarum, dimana setiap petakan dipasang 20 paku. Jarak antar paku $20 \mathrm{~cm}$. Jarum tersebut dipasang sepanjang bagian tengah petakan.

Penyemprotan dilakukan pada pagi hari ketika embun sudah hilang dan diperkirakan 4 jam sesudah penyemprotan tidak terjadi hujan. Knapsack sprayer (semprotan gendong) diisi dengan cairan semprotan sebanyak 5 L. Kalibrasi dilakukan untuk mengetahui jumlah cairan yang diperlukan untuk menyemprot petakan dengan luasan $2 \mathrm{~m} \mathrm{x} 4 \mathrm{~m}$, lebar semprotan dan kecepatan berjalan. Jumlah cairan penyemprotan adalah $500 \mathrm{~L} \mathrm{ha}^{-1}$.

Pengamatan dilakukan 30 hari setelah penyemprotan. Pengamatan dilakukan pada populasi gulma yang hidup, luasan gulma yang mati, jenis gulma yang masih hidup dan bobot kering gulma hidup. Metode pengambilan sampel menggunakan metode kuadrat ukuran $50 \mathrm{~cm}$ x $50 \mathrm{~cm}$ untuk 
lahan rawa tadah hujan dan ukuran $1 \mathrm{~m} \times 1 \mathrm{~m}$ untuk lahan rawa payau dan saluran drainase dengan 3 petak contoh setiap satuan percobaan.

\section{HASIL DAN PEMBAHASAN}

\section{Analisis Vegetasi}

Analisis vegetasi mendapatkan 21 jenis gulma di lahan rawa sawah tadah hujan. Gulma-gulma dominan ada 7 jenis yaitu Ischaemum timorense, Brachiaria paspaloides, Paspalum conjugatum, Cyperus compactus, Fimbristylis aphylla, Cyperus brevifolius, dan Echinochloa colonum. Ketujuh gulma ini menguasai lahan seluas 78.57\%. Hasil analisis vegetasi di lahan rawa payau mendapatkan 10 jenis gulma. Jenis gulma yang dominan empat jenis yaitu: Panicum paludosum, Eleocharis acutangula, Eriochloa polystachya, dan Cyperus compressus. Keempat jenis gulma ini menguasai lahan rawa payau 94.3\%. Hasil analisis vegetasi di saluran drainase menemukan $100 \%$ lahan ditutupi oleh Eceng Gondok (Eichhornia crassipes (Mart) Solms). Gulma ini adalah gulma air mengapung dari familia Pontederiaceae (berdaun lebar) (Tabel 1).

\section{Pengaruh Herbisida Formulasi Unihaz}

Perlakuan herbisida formula Unihaz 5, Unihaz 6, dan kontrol menyebabkan gulma di rawa tadah hujan mati semua. Perlakuan ini berbeda tidak nyata dengan perlakuan formula Unihaz 3 dan Unihaz 4. Namun berbeda nyata dengan perlakuan formula Unihaz 1 dan Unihaz 2 (Gambar 1). Luasan gulma yang mati terendah pada adalah perlakuan formula Unihaz 2 yaitu 78.3\% (Gambar 2), demikian juga bobot kering gulma hidup tertinggi (Gambar 3). Perlakuan herbisida pada formula Unihaz 1, Unihaz 2, Unihaz 3 dan Unihaz 4 masih ditemukan jenis gulma yang hidup (Tabel 2).

Pengujian pada lahan rawa payau menunjukkan populasi gulma hidup terendah cenderung pada perlakuan formula Unihaz 5, sedangkan tertinggi cenderung pada formula Unihaz 6 (Gambar 4). Semua perlakuan mampu memberikan luasan gulma yang mati di atas 95\%, (Gambar 5), namun masih ditemukan spesies gulma yang hidup pada setiap perlakuan termasuk perlakuan kontrol (Tabel 3). Perlakuan formula Unihaz 3 Unihaz 5 dan kontrol memberikan berat kering gulma terendah pada lahan rawa payau (Gambar 6). Perlakuan herbisida formula Unihaz 5

Tabel 1. Analisis vegetasi di lahan rawa tadah hujan, rawa payau dan saluran drainase

\begin{tabular}{|c|c|c|c|c|c|}
\hline Rawa Tadah Hujan & SDR $(\%)$ & Rawa Payau & SDR $(\%)$ & Saluran Drainase & SDR $(\%)$ \\
\hline Ageratum houstonianum & 0.24 & Panicum paludosum & 51.19 & Eichhornia crassipes & 100.00 \\
\hline Cyperus rotundus & 2.11 & Eriochloa polystachya & 12.14 & & \\
\hline Cyperus brevifolius & 6.67 & Cyperus comperessus & 7.38 & & \\
\hline Cyperus compactus & 7.38 & Melostoma malabathricum & 0.48 & & \\
\hline Cyperus imbricatus & 4.52 & Mikania micrantha & 0.24 & & \\
\hline Cyperus kyllingia & 0.48 & Ischaemum muticum & 3.33 & & \\
\hline Brachiaria mutica & 2.62 & Tetracera indica & 0.48 & & \\
\hline Brachiaria paspaloides & 17.14 & Ipomoea triloba & 0.24 & & \\
\hline Echinochloa colonum & 4.76 & Eleocharis acutangula & 23.81 & & \\
\hline Ischaemum timorense & 23.33 & Rhynchospora corymbosa & 0.95 & & \\
\hline Paspalum conjugatum & 12.62 & & & & \\
\hline Fimbristylis miliacea & 2.86 & & & & \\
\hline Fimbristylis aphylla & 6.67 & & & & \\
\hline Fimbristylis abovrulis & 0.71 & & & & \\
\hline Limnocharis flava & 1.19 & & & & \\
\hline Eragrostis uniolida & 0.95 & & & & \\
\hline Scirpus juncoides & 3.57 & & & & \\
\hline Borreria alata & 0.95 & & & & \\
\hline Eleocharis dulcis & 0.24 & & & & \\
\hline Cyperus pumilus & 0.24 & & & & \\
\hline Fuirenna umbellata & 0.71 & & & & \\
\hline Jumlah & 100.00 & & 100.00 & & 100.00 \\
\hline
\end{tabular}

Keterangan: SDR= Sum Dominance Ratio (Nilai Nisbah Jumlah Dominansi) 


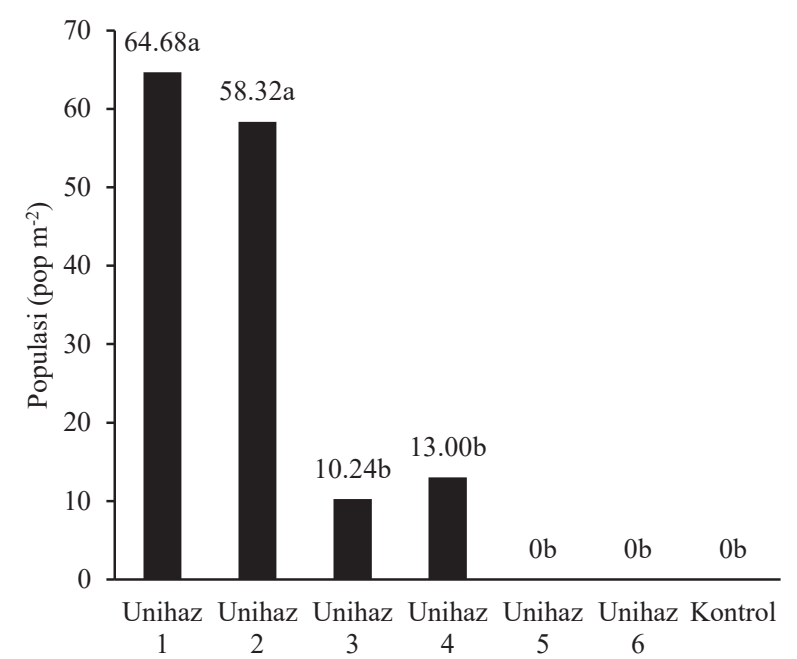

Keterangan: Angka-angka yang hurufnya sama berbeda tidak nyata pada taraf uji DMRT 0.05

Gambar 1. Populasi gulma hidup setelah penyemprotan pada lahan rawa tadah hujan

dan kontrol hanya menyisakan satu jenis gulma yang hidup yaitu Panicum paludosum dengan berat kering $12.22 \mathrm{~g} \mathrm{~m}^{-2}$ untuk formula Unihaz 5 dan $2.53 \mathrm{~g} \mathrm{~m}^{-2}$ untuk perlakuan kontrol. Masih ditemukannya jenis gulma yang hidup bukan berarti gulma tersebut tidak mati tapi diduga dikarenakan populasinya yang banyak sehingga masih menyisakan gulma hidup.

Pengujian pada gulma air di saluran drainase memperlihatkan gulma eceng gondok mati semua setelah aplikasi herbisida (Gambar 7). Hal ini menunjukkan bahwa gulma eceng gondok sensitif terhadap herbisida formula Unihaz.

Semua peubah yang diamati berpengaruh tidak nyata kecuali pada populasi gulma hidup di lahan rawa tadah hujan. Hal ini mengindikasikan gulma air lebih sensitif terhadap herbisida dibandingkan dengan gulma darat. Perlakuan pada gulma darat menunjukkan berpengaruh nyata pada peubah

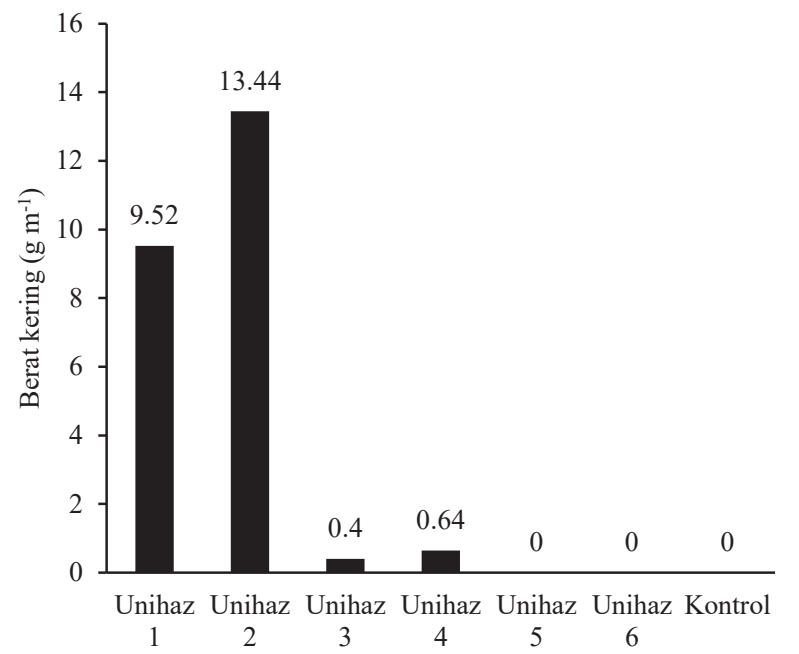

Gambar 3. Bobot kering gulma hidup pada lahan rawa tadah hujan

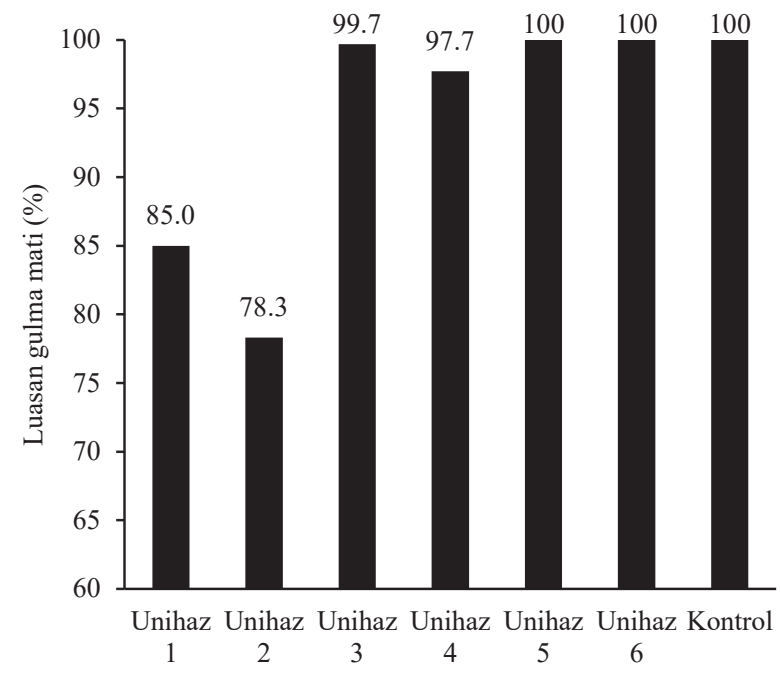

Gambar 2. Luasan gulma mati setelah penyemprotan pada lahan rawa tadah hujan

luasan gulma yang mati dan berat kering gulma yang hidup (Anwar dan Suzanna, 2016).

Air kelapa fementasi bersifat racun bagi gulma. Hasil penelitian Anwar et al. (2014) menunjukkan bahwa air kelapa fermentasi tanpa dicampur herbisida dapat menekan pertumbuhan alang-alang. Aplikasi air kelapa fermentasi dosis $300 \mathrm{~mL}$ per polibag dapat membunuh alang-alang $80.8 \%$ sedangkan dosis $400 \mathrm{~mL}$ per polibag membunuh sampai $100 \%$. Efektifitas herbisida air kelapa fermentasi meningkatkan dengan penambahan glifosat. Hasil penelitian Anwar dan Suzanna (2016) menyimpulkan

Tabel 2. Jenis gulma yang masih hidup setelah aplikasi perlakuan herbisida pada rawa tadah hujan

\begin{tabular}{llc}
\hline Formula & $\begin{array}{c}\text { Jenis gulma yang } \\
\text { masih hidup }\end{array}$ & $\begin{array}{c}\text { Berat kering } \\
\text { gulma hidup } \\
\left(\mathrm{g} \mathrm{m}^{-2}\right)\end{array}$ \\
\hline Unihaz 1 & Ischaemum timorense & 5.92 \\
Unihaz 2 & Cyperus compactus & 3.60 \\
& Cyperus rotondus & 2.40 \\
& Ischaemum timorense & 4.80 \\
Unihaz 3 & Cyperus compactus & 3.44 \\
& Ischaemum timorense & 2.80 \\
Unihaz 4 & Fimbristylis aphylla & 0.24 \\
& Cyperus compactus & 0.16 \\
& Ischaemum timorense & 0.24 \\
Unihaz 5 & Cyperus rotundus & 0.20 \\
Unihaz 6 & & - \\
Glifosat & & -
\end{tabular}




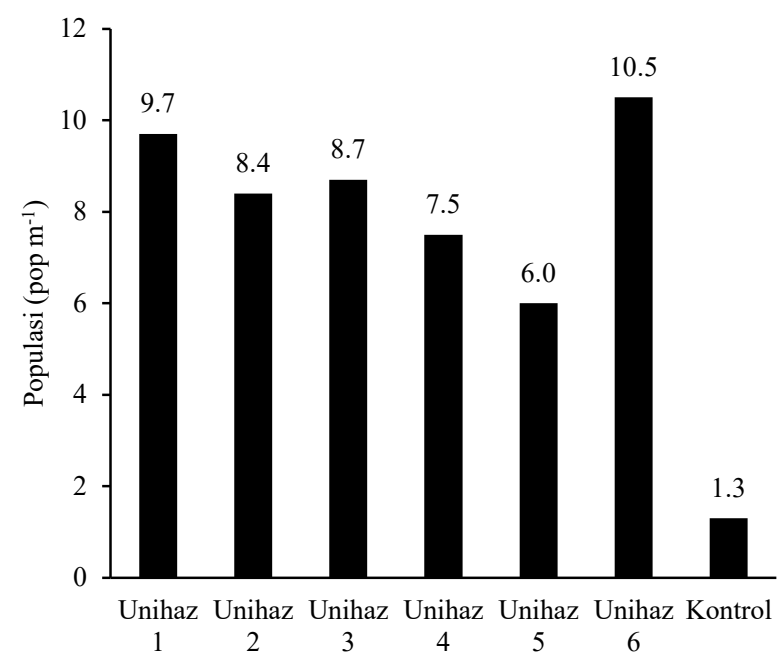

Gambar 4. Populasi gulma hidup setelah penyemprotan pada lahan rawa payau

bahwa perlakuan konsentrasi glifosat $2 \mathrm{~mL}$ dicampur dengan $200 \mathrm{~mL}$ air kelapa fermentasi mampu membunuh gulma di perkebunan kelapa sawit belum menghasilkan sebesar 93.8\%, sedangkan pada konsentrasi glifosat $4 \mathrm{~mL}$ dicampur $100 \mathrm{~mL}$ air kelapa fermentasi mampu membunuh 99.2\%. Glifosat merupakan herbisida yang mempunyai spektum pengendali yang luas dan bersifat tidak selektif. Wardoyo (2010) menyebutkan senyawa ini diserap melalui daun dan diangkut ke dalam semua jaringan tumbuhan. Cara kerjanya mempengaruhi asam nukleat dan sintesis protein yaitu menghambat enzim 5-enolpiruvil-shikimat-3-fosfat sintase

Tabel 3. Jenis gulma yang masih hidup setelah aplikasi perlakuan herbisida pada rawa payau

\begin{tabular}{llc}
\hline Formula & $\begin{array}{c}\text { Jenis gulma yang masih } \\
\text { hidup }\end{array}$ & $\begin{array}{c}\text { Berat kering } \\
\text { gulma hidup } \\
\left(\mathrm{g} \mathrm{m}^{-2}\right)\end{array}$ \\
\hline Unihaz 1 & Panicum paludosum & 3.68 \\
& Eleocharis acutangula & 2.29 \\
& Melostoma malabathricum & 4.41 \\
Unihaz 2 & Eriochioa polystachya & 0.96 \\
& Panicum paludosum & 3.85 \\
Unihaz 3 & Eleochloa polystachya & 3.87 \\
& Eleochicum palis acutangula & 4.40 \\
& Tetracera indica & 3.45 \\
Unihaz 4 & Panicum paludosum & 3.62 \\
& Eleocharis acutangula & 4.56 \\
Unihaz 5 & Panicum paludosum & 5.76 \\
Unihaz 6 & Panicum paludosum & 11.10 \\
& Eleocharis acutangula & 12.12 \\
Glifosat & Panicum paludosum & 3.46 \\
\hline
\end{tabular}

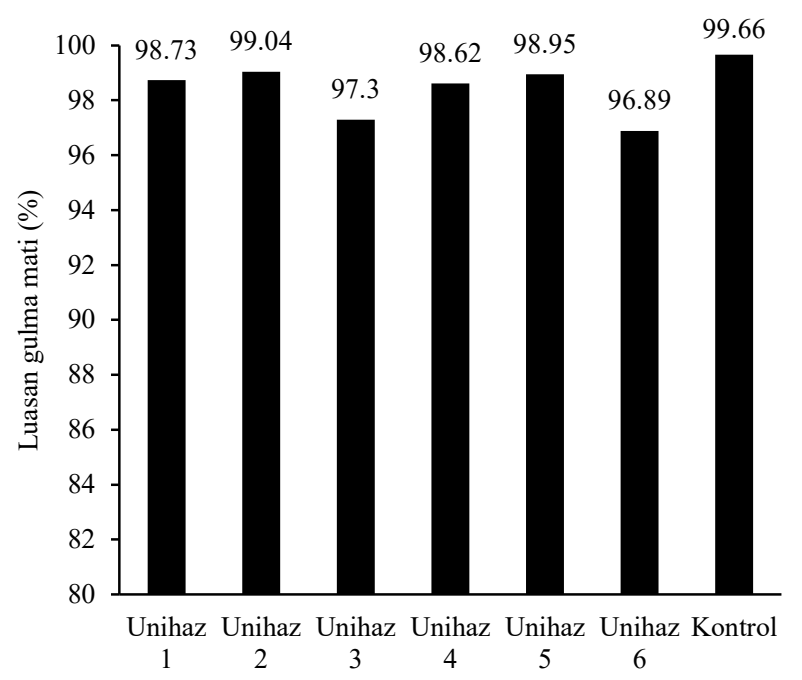

Gambar 5. Luasan gulma mati setelah penyemprotan pada lahan rawa payau

(EPSPS) yang berperan dalam pembentukan asam amino aromatik seperti triptofan, tirosin dan fenilalanin. Gulma akan mati karena kekurangan asam amino yang penting untuk melakukan berbagai proses hidupnya.

Air kelapa mengandung fitohormon dan mineral yang tinggi sehingga memacu metabolisme gulma dan memudahkan bahan aktif baik yang berasal dari fermentasi air kelapa maupun glifosat dalam membunuh gulma. Kristina dan Syahid (2012) menyebutkan air kelapa mengandung kinetin (sitokinin) $273.62 \mathrm{mg} \mathrm{L}^{-1}$ dan zeatin $290.47 \mathrm{mg} \mathrm{L}^{-1}$, dan IAA (auksin) $198.55 \mathrm{mg} \mathrm{L}^{-1}$. Selain itu disebutkan juga, air kelapa mengandung kadar mineral $\mathrm{N}, \mathrm{P}, \mathrm{K}, \mathrm{Mg}, \mathrm{Na}$, dan Zn yang tinggi.

Hasil fermentasi air kelapa mengandung etanol, asam asetat, acetaldehyde, benzaldehyde, asam laktat, asam butirat, aseton, lakton dan asam propanoat (Netty, 2002; Lee et al., 2013). Selain asam asetat dan etanol tidak banyak yang mengetahui peranan senyawa organik lainnya dalam membunuh gulma. Herbisida formula Unihaz ini mengandung etanol $0.48 \%$ dengan $\mathrm{pH}$ 3.6. Cabral et al.

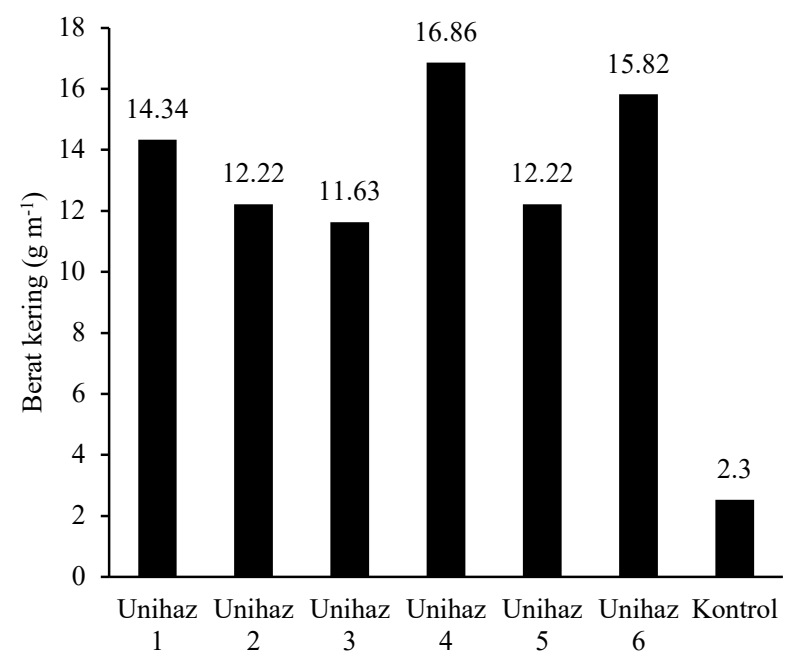

Gambar 6. Berat kering gulma hidup pada lahan rawa payau 


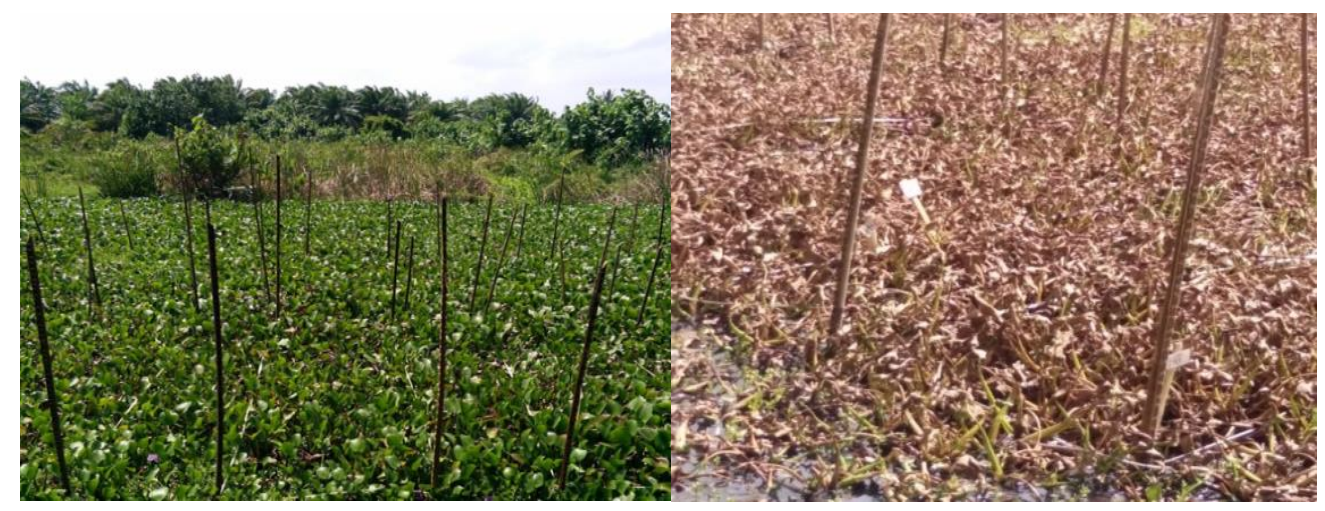

Gambar 7. Kondisi gulma sebelum dan sesudah aplikasi herbisida pada saluran drainase

(2016) menyebutkan bahwa gula yang terkandung dikonversi ke etanol sebesar 59.6\%. Kehadiran etanol ini menyebabkan lapisan lilin atau wax yang melapisi dipermukaan daun menjadi luntur sehingga bahan aktif mudah masuk ke dalam sistem jaringan gulma. Selanjutnya menuju side of action herbisida dan mengganggu sistem pembentukan asam amino. Formulasi herbisida ini mengandung asam asetat $\left(\mathrm{CH}_{3} \mathrm{COOH}\right)$ sebesar $16.3 \%$. Suryadi et al. (2017) menyebutkan asam asetat dapat dimanfaatkan sebagai herbisida karena memiliki mekanisme kerja mirip paraquat yaitu menyebabkan perusakan secara cepat keutuhan membran sel yang mengakibatkan pengeringan jaringan daun, dan akhirnya kematian gulma. Asam asetat adalah pelarut protik hidrofilik (polar), mirip seperti air dan etanol. Asam asetat bercampur dengan mudah dengan pelarut polar atau nonpolar lainnya seperti air, kloroform dan heksana. Hasil penelitian Abouziena et al. (2009) menunjukkan bahwa herbisida asam asetat (30\%) mengendalikan semua jenis gulma ketika diaplikasikan diawal pertumbuhan. Asam asetat (30\%) adalah fitotoksik untuk semua gulma berdaun lebar dan sebagian besar gulma berdaun sempit ketika diaplikasikan awal pertumbuhan gulma. Disebutkan juga, aplikasi yang tertunda sampai tahap empat hingga enam daun secara signifikan mengurangi kemanjuran. Asam asetat kurang sensitif terhadap tahap pertumbuhan dibandingkan herbisida lainnya.

Koriyando et al. (2014) menetapkan penutupan gulma kurang dari 30\% dan berat kering $14 \mathrm{~g} \mathrm{~m}^{-2}$ setelah aplikasi herbisida dikatakan efektif. Sulistyono et al. (1999) juga menetapkan penutupan gulma kurang dari 30\% dikatakan efektif. Berdasarkan kreteria tersebut herbisida formula Unihaz 3, 4, 5, dan 6 efektif dalam mengendalikan gulma di lahan rawa tadah hujan, herbisida formula Unihaz 2, 3, dan 5 efektif dalam mengendalikan gulma rawa payau dan semua formula efektif dalam mengendalikan gulma di saluran drainase. Namun ditingkat petani semakin tinggi kematian gulma semakin efektif herbisida tersebut. Penelitian ini menetapkan suatu herbisida dikatakan efektif bila kematian gulma minimal $95 \%$, populasi maksimal 6 populasi $\mathrm{m}^{-2}$ dan berat kering gulma hidup maksimal $14 \mathrm{~g} \mathrm{~m}^{-2}$. Berdasarkan kreteria tersebut herbisida formula Unihaz 5 memberikan efektifitas pengendalian gulma terbaik dibandingkan dengan perlakuan lainnya dalam mengendalikan gulma air dan berbeda tidak nyata dengan kontrol.

Formula Unihaz 5 dapat menggantikan herbisida sintetis berbahan aktif Isopropylamin $N$-(phosphonomethyl) glycine (glifosat). Herbisida ini mengandung bahan organik hasil fermentasi air kelapa ditambah dengan glifosat sebesar $10.8 \mathrm{~g} \mathrm{~L}^{-1}$ (konsentrasi 1.08\%). Apabila dosis yang digunakan untuk mengendalikan gulma adalah $50 \mathrm{~L} \mathrm{ha}^{-1}$ maka bahan aktif glifosat yang digunakan adalah $540 \mathrm{~g} \mathrm{ha}^{-1}$. Rekomendasi pabrikan dalam penggunaan glifosate adalah $2 \mathrm{~kg} \mathrm{ha}^{-1}$, dengan demikian dapat menghemat penggunaan glifosat sebesar $73 \%$.

\section{KESIMPULAN}

Terdapat 21 jenis gulma ditemukan di rawa tadah hujan. Gulma-gulma dominan ada 7 jenis yaitu Ischaemum timorense Kunth. (23.3\%), Brachiaria paspaloides (J.Presl) C.E.Hubb. (17.1\%), Paspalum conjugatum Berg. (12.6\%), Cyperus compactus Retz. (7.4\%), Fimbrystylis aphylla Steud. (6.7\%), Cyperus brevolius Rottb. (6.7\%), dan Echinochloa colonum L. (4.8\%). Tujuh gulma ini menguasai lahan $78.57 \%$. Ditemukan 10 jenis gulma di rawa payau. Gulma-gulma dominan yaitu Panicum paludosum Roxb (51.2\%), Eleocharis acutangula (Roxb.) Schult (23.8\%), Eriochloa polystachya Kunth. (11.9\%) dan Cyperus compressus L. (7.4\%). Keempat jenis gulma ini menguasai lahan rawa payau $94.3 \%$. Jenis gulma yang ditemukan di saluran drainase adalah eceng gondok (Eichhornia crassipes (Mart.) Solms) dan menguasai lahan $100 \%$. Herbisida formula Unihaz 3, 4, 5, dan 6 efektif dalam mengendalikan gulma di lahan rawa tadah hujan. Herbisida formula Unihaz 2, 3, dan 5 efektif dalam mengendalikan gulma di rawa payau. Herbisida semua formula efektif dalam mengendalikan gulma di saluran drainase. Herbisida formula Unihaz 5 lebih efektif dalam mengendalikan gulma air di rawa tadah hujan, rawa payau dan saluran drainase, dan berbeda tidak nyata dengan penggunaan herbisida glifosat dosis $2,000 \mathrm{~g} \mathrm{ha}^{-1}$. 


\section{UCAPAN TERIMA KASIH}

Ucapan terima kasih disampaikan kepada Direktorat Riset dan Pengabdian Masyarakat (DRPM) Kementerian Riset, Teknologi dan Pendidikan Tinggi (Kemenristekdikti) yang telah membiayai penelitian ini dalam skema Penelitian Strategis Nasional Institusi, tahun anggaran 2018.

\section{DAFTAR PUSTAKA}

Abouziena, H.F.H., A.A.M. Omar, S.D. Sharma, M. Singh. 2009. Efficacy comparison of some new naturalproduct herbicides for weed control at two growth stages. J. Weed Technol. 23:431-437.

Anwar, R., E. Suzanna, Yarmadi. 2013. Uji vigor gulma Echinochloa crus-gally terhadap berbagai alleloati tumbuhan. J. Agroqua 11:1-4.

Anwar, R., E. Suzanna, L.Triyono. 2014. Pengaruh dosis air kelapa fermentasi terhadap pertumbuhan alang-alang (Imperata cylindrica L). J. Agric. 10:1076-1082.

Anwar, R., F.Aryani, S. Saputra. 2015.Pengaruh penambahan fermentasi air kelapa terhadap efektifitas glifosat dalam membunuh alang-alang (Imperata cylindra L.). J. Agroqua 13:17-21.

Anwar, R., E. Suzanna. 2016. Peranan herbisida glifosate dan air kelapa fermentasi dalam mengendalikan gulma di perkebunan kelapa sawit yang belum menghasilkan. J. Agroqua 14:11-18.

Cabral, M.M.S., C.E. de Farias Silva, A.K. de Souza Abud, R.M.R.G. Almeida. 2016. Bioethanol production from coconut husk fiber. J. Ciência Rural, Santa Maria 46:1872-1877.

Geremew, A., I. Stiers, T. Sierens, A. Kefalew, L. Triest. 2018. Clonal growth strategy, diversity and structure: A spatiotemporal response to sedimentation in tropical Cyperus papyrus swamps. PLoS ONE 13:119.

Koriyando, V., H. Susanto, Sugiatno, H. Pujisiswanto. 2014. Efikasi herbisida metil metsulfuron pada tanaman kelapa sawit (Elaeis guineensis Jacq.) menghasilkan. J. Agrotek Tropika 2:375-381.
Kurniawan, S., Y. Kurniawati, D. Sandri, Fatimah. 2014. Efektifitas air kelapa fermentasi sebagai larutan penghemat herbisida komersil. J. Teknologi AgroIndustri 1:19-23.

Kristina, N.N., S.F. Syahid. 2012. Pengaruh air kelapa terhadap multiplikasi tunas in vitro, produksi rimpang, dan kandungan xanthorrhizol temulawak di lapangan. J. Littri 18:125-134.

Netty, W. 2002. Optimasi medium untuk multiplikasi tunas kana (Canna hibryda Hort.) dengan penambahan sitokinin. J. Biosains Bioteknol. Indonesia 2: 27-31.

Lee, P.R., C.X. Boo, S.Q. Liu. 2013. Fermentation of coconut water by probiotic strains Lactobacillus acidophilus L10 and Lactobacillus casei L26. Ann. Microbiol. 63:1441-1450.

Sulistyono, E., A.P. Lontoh, H. Widagdo. 1999. Studi efektivitas pencampuran surfaktan dengan herbisida untuk jalur tanaman karet belum menghasilkan. Bul. Agron. 27:25-29.

Supriadi, A. Sudirman, E. Jauhariya, S. Rahayuningsih. 2012. Pengembangan formulasi herbisida berbasis asam asetat untuk mengendalikan gulma pada tanaman kelapa sawit. Kementrian Pertanian (Unit Kerja). diakses melalui http://pkpp.ristek.go.id/index. php/ penelitian/detail/785 (24 Oktober 2012).

Suriadikarta, D.A., M.T. Sutriadi. 2007. Jenis-jenis lahan berpotensi untuk pengembangan pertanian di lahan rawa. J. Litbang Pertanian 26:115-122.

Suryadi, M.A., H. Pujisiswanto, N. Sriyani. 2017. Pengaruh campuran asam asetat dan ekstrak buah lerak sebagai herbisida terhadap gulma Paspalum conjugatum, Cyperus kyllingia dan Asystasia gengetica. hal. 6472. Prosiding Seminar Nasional Pengembangan Teknologi Pertanian VI, Politeknik Negeri Lampung. Lampung 07 September 2017.

Wardoyo, S.S. 2010. Pengaruh residu herbisida glifosat terhadap ciri tanah pertumbuhan tanaman. J. Ilmu Pert. Indonesia 10:40-45. 